\title{
Building Density Level of Urban Slum Area in Jakarta
}

\author{
Tenty Melvianti Legarias ${ }^{1}$, Renny Nurhasana ${ }^{1}$, Edy Irwansyah ${ }^{2}$ \\ ${ }^{1}$ Urban Studies Program, School of Strategic and Global Studies, Universitas Indonesia, \\ Jakarta, 10430, Indonesia \\ ${ }^{2}$ School of Computer Sciences, Bina Nusantara University, Jakarta, 11480, Indonesia \\ *Corresponding Author: melvi.legarias@gmail.com
}

Received 10 July 2020/ Revised 6 August 2020 / Accepted 11 August 2020/ Available Online 15 August 2020

\begin{abstract}
Currently, the number of urban residents is increasing and some of the urban population live in slum areas. Therefore, identifying the characteristics of slum areas has become crucial. This study aimed to identify more specific slum locations in Jakarta through the pattern of building densities analysis between case studies of neighborhoods association (RT) in 15 hamlets (RW) that classified as heavy slums category. This study also attempted to determine the relation between building density levels in the slum area and Jakarta spatial detail planning. This study engaged the Cluster and Outlier Analysis (Anselin Local Moran's I) method. This study also observed socio-economic factors of citizen census data based the Dasawisma Census of Family Welfare Empowerment in 2019. The result shows that slum locations that had direct neighbors towards areas which was designated at spatial detail planning as industrial zones and ware housing areas as well as office, trade and service zones, obtained a higher level of building density compared to slum locations that secured neighbors to areas that were designated as housing zones. High economic opportunities provided attraction and affected the growth of slum locations. The results also reveal that slum areas were not a concentrated population with low income and/or low education. Applying cluster and outlier modeling of building density levels of urban slums in Jakarta based on RT cluster level could reveal more specific slum locations and could identify factors that influence the differences of building density levels.
\end{abstract}

Keywords: Slums; Spatial Detail Planning; Cluster and Outlier Analysis; Geographic Information System

\section{Introduction}

By 2030, the cities population are projected to be increased up to 60 percent with 1 of 4 city residents living in slums (United Nations, 2019). The phenomenon of rapid urbanization affects escalation of slums, increasing the number of infrastructure and inadequate services (such as sewage treatment facilities, availability of clean water and sanitation, roads, and transportation), as well as escalation of air pollution and also influences cities expansion that are unplanned. Some people settled and struggled in slums, sometimes those were only a few meters away from the upper community and commercial areas. 
There are several definitions and conditions to define slums. The most convenient of 'slum' term is a dense urban area that does not meet the standard housing conditions and indicates poverty area (UN Habitat, 2004). This explanation contributes to the main characteristics of slums which are performing high density and low housing standards (structure and services), and poverty. In Indonesia, slum is defined as inappropriate settlement to live, due to erratically building, the presence of high density, low-quality buildings, facilities and amenities shortages, and low affordability of infrastructure(Ministry of Public Works and Indonesian Public HousingPUPR, 2016). There are several methods could be utilized to identify slums in a city or region and to determine whether the certain area could affect slums escalation. Each slum performs different conditions, slums may develop or new slums may emerge, both could be enhanced through high rural-urban migration rates or location circum stance that usually being indicated as inappropriate for housing (river banks, steep slopes, landfills, uninhabitated land, railroad lines, adjacency towards industrial areas or markets and all over river banks) (Roy et al., 2014).

In Lagos, Nigeria, a study of slums characteristics was performed through a census using respondents from 120 slums as samples, and the results showed that $7.7 \%$ of respondents received incomes above US \$ 352.94, 13.8\% were graduated of formal education and 67\% were non-native, also, $5.6 \%$ of buildings were built with wood, while $91.5 \%$ of buildings were more 10 years (Adedayo \& Malik, 2015). Research relating slum was also performed engaging questionnaires towards respondents, revealed that the major factors affecting slums were affordability, cultural, kinship and markets adjacency, and then followed by other factors (Badmos et al., 2020). Friesen et al. (2018) also utilized population data of slum area to indicate that slum development was strongly related to demographic development of a country.

Some studies utilizing building maps and spatial methods to identify urban areas based on building density levels. Buildings data could be used to describe community residence or to describe a business district within down town compared to population data (De Bellefon et al., 2020). High density is also one of the physical characteristics that is frequently used to describe slums. Furthermore, in term of physical characteristics, there are also the small roof size and irregular patterns (Kuffer et al., 2016). Spatial statistical method also measures spatial concentration including high-density buildings. Arribas-Bel et al. (2019) also engaged building density measurements based on machine learning algorithms, proposed to obtain the distribution of building groups with significant values that could reach the minimum building density limit. De Bellefon et al. (2020) compared building density with engaging building data in France. Hence, the definition of urban area is characterized by high building density.

Few researchers combined some methods to draw slum characteristics. The Object-Based Slum Detections research in Jakarta by Pratomo et al. (2017) conducted Object-Based Image 
Analysis (OBIA) with distance variable upon the river or railroad, building size, building density, roofing materials, and illegal land expansion. All of these variables were taken from expert agreements. Similar research employed remote sensing to identify slum areas was conducted in Bandung (Leonita et al., 2018) performed a method which combining remote sensing imagery with machine learning by gathering all the input from the experts based on slum indicators.

Wijaya et al. (2019) conducted a field study of a slum located in Kelurahan Manggarai, South Jakarta, to calculate the usage intensity of communal space occupied by slum residents. The results showed the communal space usage not only in public locations that already remained in spatial planning, but also communal space utilization also occupied a huge of space for roads. In the same location, Wati (2018) revealed that due to improper housing space conditions, the private space engagement spread out and utilized public space.

Slum issues and spatial detail planning are closely interrelated. This is comformable to the New Urban Agenda which is committed to promote the planning and replenishment of city expansion, includes a commitment to recover slums. Slums in Jakarta were classified using RW (Rukun Warga/hamlet) administrative boundaries and there was still limited information regarding slums in the smaller areas or certain slum locations and limited information to determine the effect of spatial detail planning factors on these locations.

The previous studies concerned in identifying the characteristics of slums based on the population census, field study and remote sensing methods. There have been limited studies focused on slum areas interrelated to spatial detail planning in Jakarta using building density. Therefore, this study aimed to identify more specific slum locations in Jakarta through the pattern of building density analysis between case studies neighborhoods association (RT) in 15 hamlets (RW) that classified as heavy slums category. This study committed to investigate the affiliation between building density level in slum area and Jakarta spatial detail planning. The current research also observed socio-economic factors based on population census data reported by the Dasawisma Census of Family Welfare Empowerment in 2019.

\section{Methods}

\subsection{Study Area}

The study area employed in this study was Jakarta Municipality. Jakarta Municipality was the capital city which was divided into five regions (Kota Administrasi) composed of 42 sub-district (Kecamatan) that consisted of 262 urban villages (Kelurahan) and divided into 2,718 citizen associations $(R W)$. Each RW was divided into 10-20 neighborhoods $(R T)$. Jakarta is the capital and largest city of Indonesia that covers 662,33 square kilometers. 
Jakarta Provincial Government had classified 445 RW as slums according to DKI Jakarta Provincial Governor Regulation Number 90/2018 related to Improvement of Quality of Settlements in the Context of Integrated Housing Area Regulations, which are categorized as heavy, medium, light and very light priority. However, $15 \mathrm{RW}$ of $445 \mathrm{RW}$ were categorized as heavy slum were selected for this study namely: West Jakarta with seven locations consisted of Jati Pulo urban village RW 006, RW 008, RW 009, Kapuk urban village RW 012, RW 016, Jembatan Besi urban village RW 003, Keagungan urban village RW 003, North Jakarta with four locations consisted of Kalibaru urban village RW 004, RW 007, Penjaringan urban village RW 008, RW 017, East Jakarta with two locations consisted of Kampung Melayu urban village RW 007, RW 008, South Jakarta with one location namely Manggarai urban village RW 004 and Central Jakarta with one location namely Tanah Tinggi urban village RW 012.

These 15 locations were considered as heavy slums category were taken as samples, since those were assumed to be locations with the highest slum level compared to others. It was necessary to analyze these fifteen (15) locations as priority locations to improve slums and the analysis results could be utilized as references for other categories. The distribution of fifteen RW locations is presented in Figure 1 with heavy slum legend.

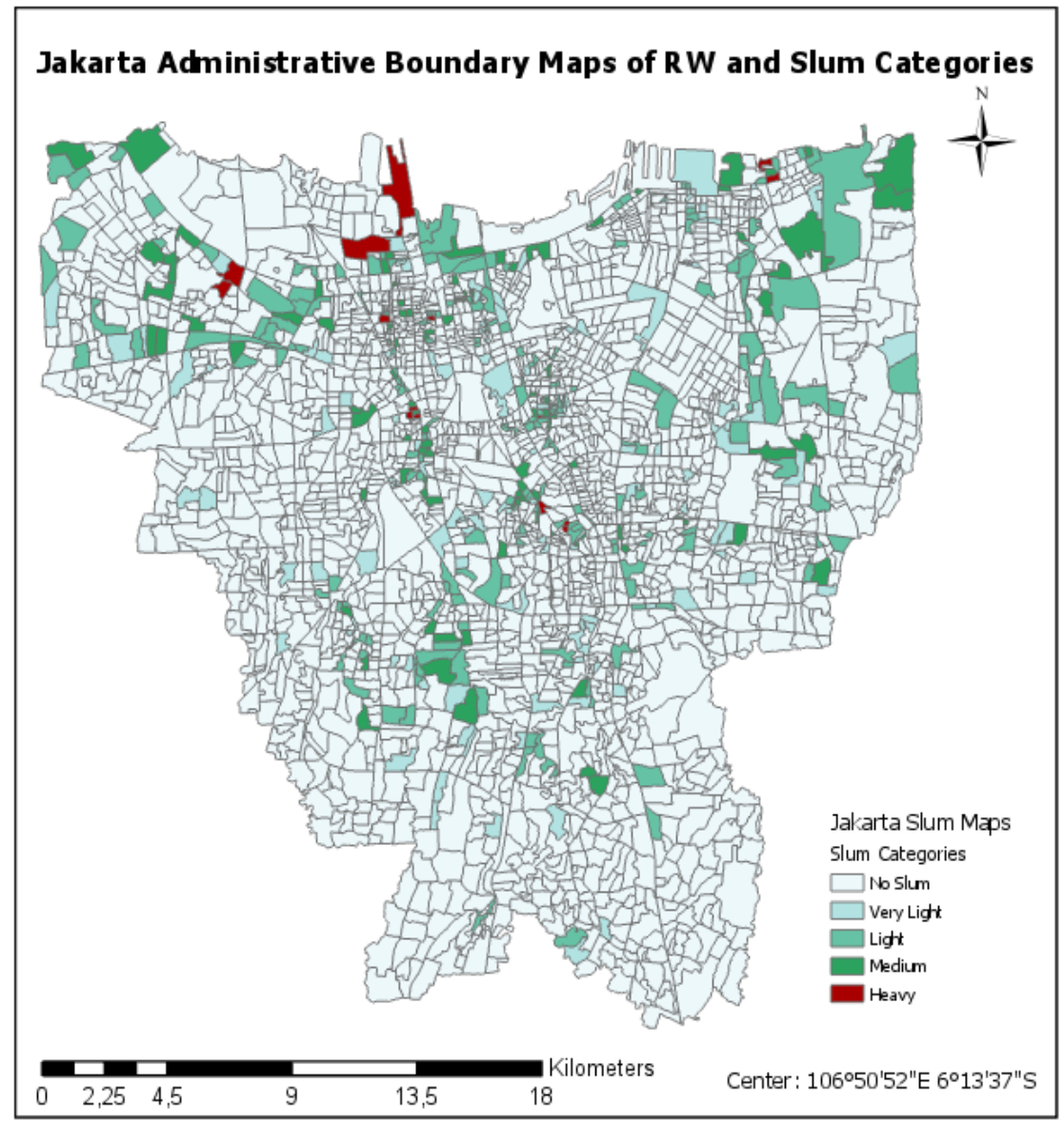

Figure 1. Jakarta Slum Maps 


\subsection{Data Resources}

Spatial data sources were building map, administrative boundary map, and the spatial detail planning map provided by Human Settlement, Spatial Planning and Land Authority Department of Jakarta Provincial Government, and citizen census data reported by the Dasawisma Census of Family Welfare Empowerment in 2019. Jakarta buildings map dataset in GIS format which mapped in National Geospatial Standard precision for the year 2019 was taken from aerial photography in 2014. The building map was engaged to generate building density levels by overlaying it along with administrative boundary map of RW. All maps were officially published online at https://jakartasatu.jakarta.go.id.

Jakarta administrative boundary maps composed of areas boundaries (Kota Administrasi), sub-district (Kecamatan), urban villages (Kelurahan), hamlets $(R W)$, and neighborhoods association $(R T)$. This research employed RW and RT administrative boundary maps. A smaller scale of analysis unit of RW was required to determine the focus of slum locations within RW area, thus this research utilized RT map scale. The current study also utilized Jakarta Spatial Detail Planning Map, a map with detailed plans on district-level spatial planning which was equipped with zoning regulations that were translations for 2011-2030 Regional Spatial Plan with a map scale of 1: 5,000 (Jakarta Regional Regulation, 2014). Zoning is the regions division into zones based on original functions and characteristics or directed to the development of other functions.

Other data resources were data sets reported by the Dasawisma Census of Family Welfare Empowerment in 2019. This data was generated from census results by Jakarta Provincial Family Welfare Empowerment conducted from January to May 2019. Collection data method used by Dasawisma was over direct interviews by Dasawisma Officers towards each family member then conducted input data online through both mobile applications and web applications.

Data analysis employed dependent and independent variables. The dependent variable was building density level which was one of the physical indicators of slums (Ministry of Public Works and Indonesian Public Housing-PUPR, 2016). A high level of building density that located within metropolitan cities and large cities is $>250$ units/Ha, this parameter is engaged for Jakarta. The parameter value was 5 if the building density was in the range of $76 \%-100 \%$ of the indicator, the value 3 was if the building density was in the range of $51 \%-75 \%$ of the indicator, and the value was 1 if the building density was in the range of $25 \%$ - 50 of the indicator, a value of 5 was categorized a high score, a value of 3 was categorized a medium score and a value of 1 is categorized a low score. 
The independent variables employed for this study were taken from two sources. The first source was acquired based geographical factors, namely the spatial detail planning map and the second source was socio-economic factor,which was according to Dasawisma data composed of education, level of family activity in the settlement, and income which was represented by the head of the family.

\subsection{Analysis Method}

The research methods used were descriptive analysis and spatial analysis to accomplish the research objectives that related to spatial/regional aspects. Overlay analysis is an operation of GIS to superimpose several layers of a dataset which representing different themes together to analyze or identify the relationships of each layer. Overlay analysis represents a composite map with a combination of various attributes and the geometry of a data set or entity. An overlay is an operation of comparing variables among several scopes. During analysis process with applying overlay method, a new map could be generated which wasa combination two or more layers of input maps results. This current study, overlay analysis was performed between building maps, administrative boundary maps, and the spatial detail planning map.

In addition, Local Moran's I index (LMI) was applied to detect the clusters and outliers based on dependent variables building density level in neighborhoods (RT) administrative boundary maps. This spatial analysis namely Cluster and Outlier Analysis. The analysis was needed to be completed in order to identify the geographical distribution of slum phenomenon and to determine the factors statistically whether result in dependence phenomenon on other regions or it was an independent phenomenon. In order to formulate statistical calculations into clusters and outliers, LMI calculated the Moran I value, z-score, p-value, co-type. Z-score is the standard deviation, and the p-value is the opportunity value of mistrust that spatial patterns are random.

The Local Moran's I statistic of spatial association (Anselin, 1995) is presented below:

$$
I i=\frac{x i-\bar{X}}{S_{i}^{2}} \sum_{j=1, j \neq i}^{n} W_{i, j}\left(x_{i}-\bar{X}\right)
$$

Where $x_{i}$ is attribute for feature $i, \underline{X}$ is the mean of the corresponding attribute, $w_{i, j}$ is the spatial weight between feature $i$ and $j$, and:

$$
S_{i}^{2}=\frac{\sum_{j=1, j \neq i}^{n}(x i-\bar{X})^{2}}{n-1}
$$

With $n$ equating to the total numbers of features.

The $Z I_{i}$ score for the statistics are computed as: 


$$
Z I_{i}=\frac{I_{i}-E\left[I_{i}\right]}{\sqrt{V\left[I_{i}\right]}}
$$

where:

$$
\begin{aligned}
& E\left[I_{i}\right]=-\frac{\sum_{j=1, j \neq i}^{n} w_{i j}}{n-1} \\
& V\left[I_{i}\right]=E\left[I_{i}^{2}\right]-E\left[I_{i}\right]^{2}
\end{aligned}
$$

The result I value reveals the positive or negative value of the feature. If the value of I was positive, it meant that the feature was part of a cluster with neighboring features that were equally high or low value, whereas if the value of I was negative then the feature was an outlier where the feature had a different value than its neighbors. In both conditions, the p-value must be of very small value, thus it could be considered a significant value. In the sense of this statistic, a maximum p-value of 0.05 , could be categorized as significant was set at a $95 \%$ confidence level. Co-type on statistical results was an attribute that distinguished whether a high-value significant cluster $(\mathrm{HH})$, or a low-value significant cluster (LL), and for the outlier category would distinguish whether a feature was surrounded by high-value features $(\mathrm{LH})$ or whether a feature was surrounded by low value features (HL). The Co-type statistical results of RT area conducted in this study is presented on Figure 2.

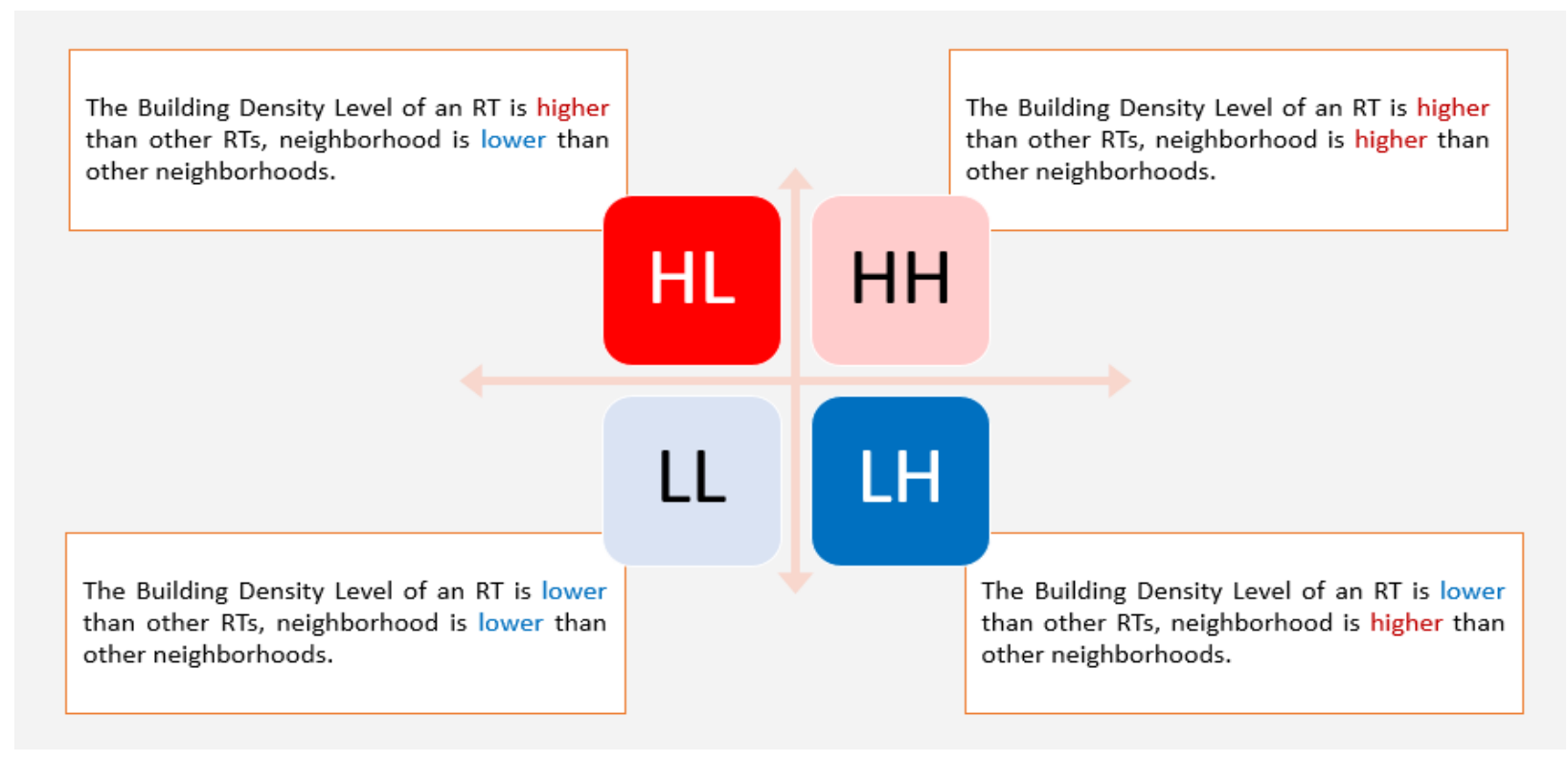

Figure 2. Cluster type for each significant feature statistically

Source: Author's Illustration. 


\section{Results and Discussion}

\subsection{Distribution of 15 RW's Building Density Level of Heavy Slums}

The initial stage was observing the distribution of the building density level of 15 RW's in heavy slum which limited the scope of this study to identify the characteristics of each RW. Spatial overlay analysis was performed between the administrative boundary map of 15 RW and the building map to calculate the level of building density. The results can be seen on Table 1 .

Table 1. Distribution of 15 RW's Building Density Level of Heavy Slums

\begin{tabular}{ccccc}
\hline Location & $\begin{array}{c}\text { Number of } \\
\text { Buildings }\end{array}$ & $\begin{array}{c}\text { RW Area } \\
\text { (Hectare) }\end{array}$ & $\begin{array}{c}\text { Building } \\
\text { Density Level } \\
\text { (Units/ha) }\end{array}$ & $\begin{array}{c}\text { Score of } \\
\text { Building } \\
\text { Density }\end{array}$ \\
\hline Jati Pulo RW 009 & 849 & 5.79 & 146.62 & Medium \\
Jati Pulo RW 008 & 606 & 4.28 & 141.60 & Medium \\
Jati Pulo RW 006 & 600 & 4.40 & 136.44 & Medium \\
Kapuk RW 016 & 4645 & 42.17 & 110.13 & Low \\
Kalibaru RW 004 & 1273 & 11.63 & 109.42 & Low \\
Tanah Tinggi RW 012 & 204 & 2.09 & 97.79 & Low \\
Kampung Melayu RW 008 & 415 & 4.28 & 97.00 & Low \\
Kampung Melayu RW 007 & 321 & 3.32 & 96.76 & Low \\
Kalibaru RW 007 & 1523 & 17.38 & 87.64 & Low \\
Kapuk RW 012 & 3475 & 41.13 & 84.48 & Low \\
Jembatan Besi RW 003 & 677 & 10.14 & 66.76 & Low \\
Keagungan RW 003 & 185 & 4.11 & 45.10 & Low \\
Manggarai RW 004 & 305 & 11.21 & 27.20 & Low \\
Penjaringan RW 017 & 4607 & 181.97 & 25.32 & Low \\
Penjaringan RW 008 & 1904 & 103.25 & 18.44 & Low \\
\hline
\end{tabular}

The building density score of RW could not yet indicate that the RW location was a heavy slum area, the scores were in between low and medium, referring to the indicator of the building density level with the highest level was 146.62 units/ha. Considering these results, it was necessary to perform deeper observations upon smaller units of analysis to focus on certain areas within the RW boundaries which were considered slum based on building density and whether the neighborhood factors within the RW boundaries affect the location or not, which in the current study were applied using RT boundary maps which were fractions of RW boundary maps. The analysis was completed using Cluster and Outlier Analysis.

\subsection{Cluster and Outlier Analysis}

During this analysis phase, six samples were taken of 15 RW's in heavy slum which gained a total of more than 1,000 buildings. The six locations were Kapuk RW 016 with 4,645 
buildings, Penjaringan RW 017 with 4,607 buildings, Kapuk RW 012 with 3,475 buildings, Penjaringan RW 008 with 1,904 buildings, Kalibaru RW 007 with 1,523 buildings and Kalibaru RW 004 with total 1,273 buildings. These six locations were also the largest RW area out of 15 RW's within heavy slum areas. In addition, based on RT boundary maps analysis, the exact RW location was also presented with a spatial detail planning map that would be applied for further observation.

\subsubsection{Kapuk RW 016}

In Kapuk RW 16 area, $69.78 \%$ of the area was planned as a residential zone, $28.24 \%$ as a green open space or blue open space zone, and $1.98 \%$ as a social and government zone. The results of the analysis identified $\mathrm{HH}$ clusters from four RT areas with an average level of building density was 173.83 units/Ha, which was identified into medium category, and this cluster occupied a residential zone and then grew in the green open space zone. LL cluster was also identified as a residential zone, but it had more old buildings. LH cluster was an area that covered the social and government zone and also green open space/blue open space zone near Kali Apuran Bawah river. Cluster and outlier analysis formulated map and spatial detail planning map for Kapuk RW 16 that could be observed on Figure 3. The Cluster and outlier analysis result is presented on Table 2 .
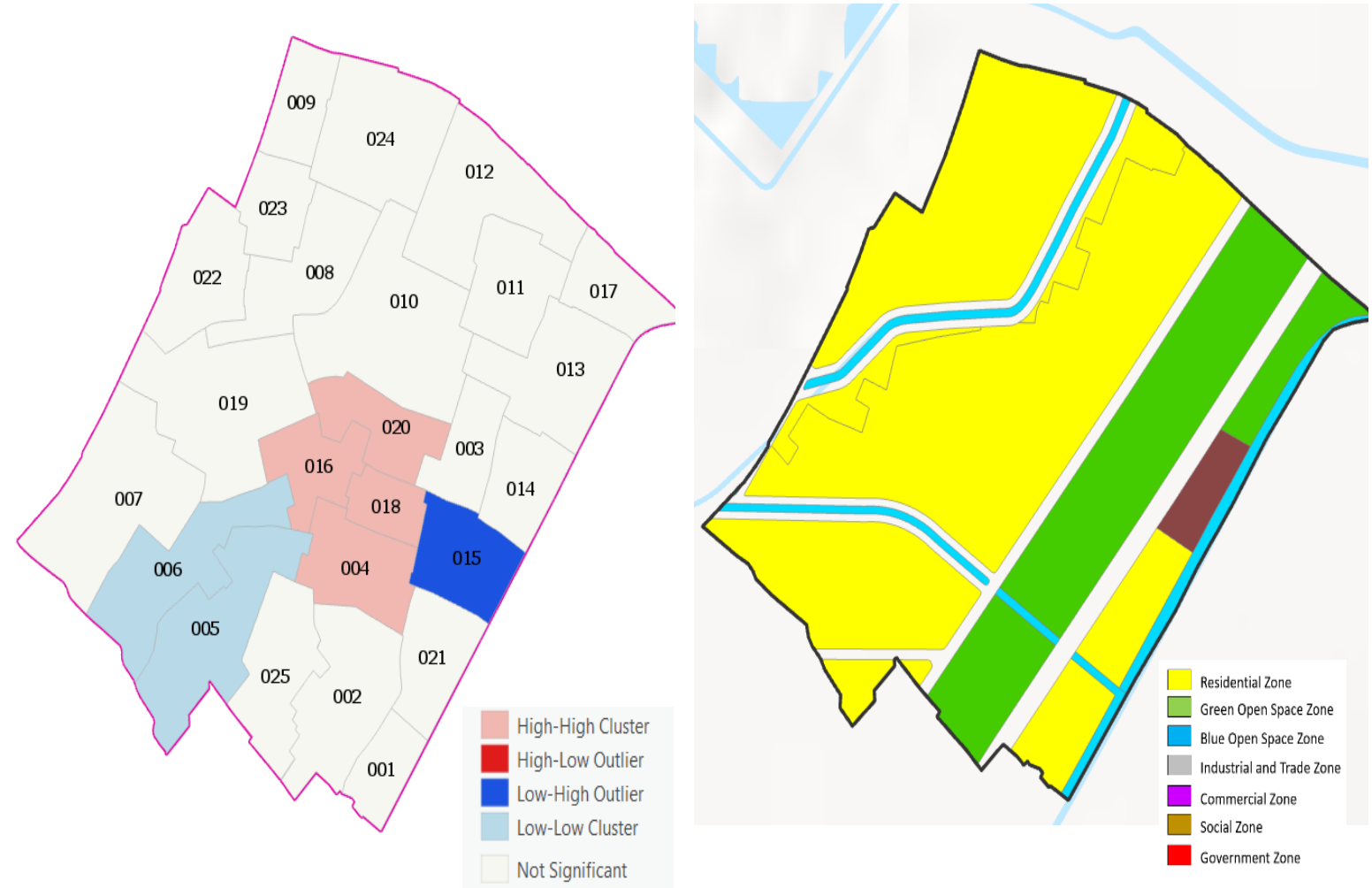

Figure 3. (a) Cluster and outlier analysis results map, (b) Spatial detail planning map 
Tenty Melvianti Legarias et al / GEOSI Vol 5 No 2 (2020) 268-287

Table 2. Cluster and Outlier Analysis Results of Kapuk RW 016

\begin{tabular}{|c|c|c|c|c|c|c|c|c|}
\hline $\begin{array}{c}\text { RT } \\
\text { Number }\end{array}$ & Area (Ha) & $\begin{array}{c}\text { Building } \\
\text { Density Level }\end{array}$ & Lmi Index & Z-Score & P-Value & $\begin{array}{l}\text { Co- } \\
\text { Type }\end{array}$ & $\begin{array}{c}\text { Neigh- } \\
\text { bors }\end{array}$ & Spatial Lag \\
\hline 001 & 0.78890752 & 131.827873 & 0.001508562 & 0.387145471 & 0.364 & - & 2 & -0.004701344 \\
\hline 002 & 2.14651369 & 140.6932558 & $5.4235 \mathrm{E}-05$ & 1.214925052 & 0.108 & - & 3 & -0.018824558 \\
\hline 003 & 1.00498735 & 172.14147 & 0.033296671 & 1.825571949 & 0.052 & - & 4 & 0.029592984 \\
\hline 004 & 1.46244218 & 148.3819347 & 0.0123515 & 2.991055859 & 0.006 & $\mathrm{HH}$ & 2 & 0.045258697 \\
\hline 005 & 2.46784838 & 103.7340875 & 0.02905614 & 1.566515726 & 0.038 & LL & 2 & -0.021869871 \\
\hline 006 & 2.14748691 & 114.5525026 & 0.030704491 & 2.340752554 & 0.004 & LL & 2 & -0.032645604 \\
\hline 007 & 3.00384643 & 90.88347439 & 0.015047986 & 1.104568131 & 0.178 & - & 1 & -0.008408863 \\
\hline 008 & 1.80339314 & 149.7177701 & 0.000924891 & 0.147887924 & 0.422 & - & 3 & 0.002882855 \\
\hline 009 & 0.9364856 & 134.5455812 & -0.0014358 & -0.455550344 & 0.322 & - & 2 & 0.006427158 \\
\hline 010 & 3.26639455 & 111.7440022 & -0.007981297 & -0.557024516 & 0.29 & - & 2 & 0.007664893 \\
\hline 011 & 1.46873319 & 169.5338549 & 0.007327559 & 0.688213256 & 0.228 & - & 2 & 0.007102963 \\
\hline 012 & 2.37001674 & 157.8047922 & 0.006688868 & 1.075411377 & 0.212 & - & 1 & 0.010949147 \\
\hline 013 & 2.08209823 & 142.6445668 & 0.000792132 & 0.831162656 & 0.208 & - & 3 & 0.011803195 \\
\hline 014 & 1.13174822 & 153.7444433 & 0.005909034 & 0.857355567 & 0.204 & - & 3 & 0.012700498 \\
\hline 015 & 1.3356222 & 136.266079 & -0.004879763 & -1.900817882 & 0.036 & LH & 4 & 0.0301812 \\
\hline 016 & 1.09323106 & 178.370343 & 0.043264785 & 2.293780083 & 0.016 & $\mathrm{HH}$ & 3 & 0.032081698 \\
\hline 017 & 1.00928455 & 135.7397179 & -0.000103513 & -0.020345199 & 0.428 & - & 1 & 0.000573283 \\
\hline 018 & 0.67348341 & 212.3289118 & 0.078562803 & 2.109136513 & 0.018 & $\mathrm{HH}$ & 5 & 0.030608937 \\
\hline 019 & 3.03095282 & 116.7949555 & 0.004076958 & 0.672323026 & 0.28 & - & 1 & -0.004740077 \\
\hline 020 & 1.2031728 & 156.2535327 & 0.0244037 & 2.514767948 & 0.012 & $\mathrm{HH}$ & 4 & 0.043950037 \\
\hline 021 & 1.2412121 & 123.2666035 & 0.00242926 & 0.42138908 & 0.36 & - & 3 & -0.003868443 \\
\hline 022 & 1.52970121 & 122.8998175 & -0.003649544 & -0.394841901 & 0.322 & - & 3 & 0.005692408 \\
\hline 023 & 0.93869414 & 173.6454862 & -0.003607513 & -0.100977414 & 0.492 & - & 3 & -0.003059541 \\
\hline 024 & 2.377284 & 127.8770227 & 0.000913782 & 0.204525798 & 0.454 & - & 1 & -0.001975342 \\
\hline 025 & 1.64110897 & 113.947339 & 0.013429807 & 1.086381045 & 0.134 & - & 2 & -0.013956718 \\
\hline
\end{tabular}

\subsubsection{Penjaringan RW 017}

In Penjaringan RW 17 area, $43.74 \%$ of the area was designed as an industrial and trade zone, $32.28 \%$ as a commercial zone, $18.89 \%$ as green open space or blue open space zone, only $4.38 \%$ as a residential zone, and $0.71 \%$ as a social and government zone. HH cluster was an RT area with $100 \%$ in green open space or blue open space zone. This area had the densest population in Jakarta. HL cluster was also location extension occupied by residents who arrived into risky zone location (green open space or blue open space zone). The LH and LL locations were industrial zones which the edges were occupied as residences by dwellers. Cluster and outlier analysis results map and spatial detail planning map for Penjaringan RW 17 are presented on Figure 4. The map shows the impact of industrial zones and commercial zones towards slum areas. The Cluster and outlier analysis results are shown on Table 3. 

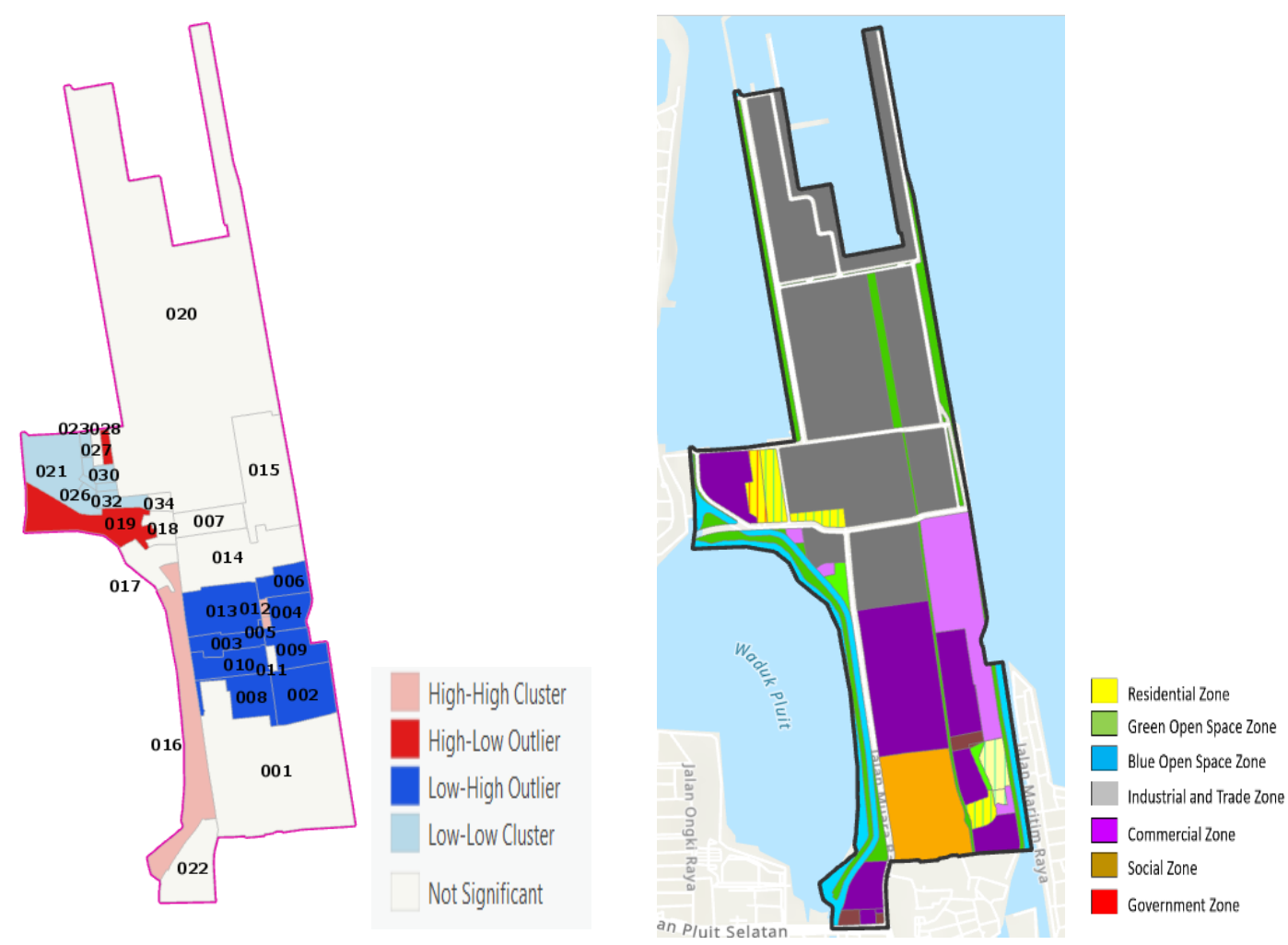

Figure 4. (a) Cluster and outlier analysis results map, (b) Spatial detail planning map

Table 3. Cluster and Outlier Analysis Results of Penjaringan RW 017

\begin{tabular}{|c|c|c|c|c|c|c|c|c|}
\hline RT Number & Area $(\mathrm{Ha})$ & $\begin{array}{c}\text { Building Density } \\
\text { Level }\end{array}$ & Lmi Index & Z-Score & P-Value & $\begin{array}{l}\text { Co- } \\
\text { Type }\end{array}$ & $\begin{array}{c}\text { Neigh- } \\
\text { bors }\end{array}$ & Spatial Lag \\
\hline 001 & 24.6804102 & 39.78864177 & -0.002616779 & -1.670152585 & 0.064 & - & 9 & 0.010441781 \\
\hline 002 & 4.824186568 & 33.99536848 & -0.007855146 & -2.531712022 & 0.01 & $\mathrm{LH}$ & 12 & 0.024575347 \\
\hline 003 & 2.085333118 & 32.60869902 & -0.011999175 & -2.346268865 & 0.028 & $\mathrm{LH}$ & 16 & 0.035695071 \\
\hline 004 & 2.049918123 & 9.756487235 & -0.038284232 & -3.577396182 & 0.004 & $\mathrm{LH}$ & 14 & 0.062921035 \\
\hline 005 & 0.139748327 & 329.1631544 & 0.15481202 & 3.271550776 & 0.004 & $\mathrm{HH}$ & 17 & 0.048418412 \\
\hline 006 & 2.118680853 & 34.45540177 & -0.010985832 & -2.55834858 & 0.012 & $\mathrm{LH}$ & 16 & 0.034969605 \\
\hline 007 & 2.618886236 & 45.82100525 & 0.000703032 & 0.492226613 & 0.308 & - & 23 & -0.003933508 \\
\hline 008 & 3.253114738 & 49.18363258 & -0.003363218 & -1.995818093 & 0.04 & LH & 13 & 0.024254728 \\
\hline 009 & 2.755275956 & 29.03520419 & -0.019206518 & -3.225429746 & 0.002 & $\mathrm{LH}$ & 13 & 0.050712012 \\
\hline 010 & 2.875708737 & 30.25341157 & -0.011723986 & -2.070478514 & 0.034 & $\mathrm{LH}$ & 15 & 0.032189144 \\
\hline 011 & 0.32690227 & 281.429676 & 0.053681346 & 1.780152457 & 0.052 & - & 13 & 0.020421872 \\
\hline 012 & 0.220512094 & 276.628818 & 0.137826164 & 3.296947998 & 0.01 & $\mathrm{HH}$ & 17 & 0.053599316 \\
\hline 013 & 5.350504813 & 27.47404313 & -0.013279142 & -2.509172762 & 0.01 & $\mathrm{LH}$ & 18 & 0.033420202 \\
\hline 014 & 9.009023645 & 31.85694824 & -0.005614526 & -1.576171251 & 0.068 & - & 18 & 0.016268559 \\
\hline 015 & 8.638203131 & 11.11342238 & -0.003542517 & -0.845140368 & 0.204 & - & 11 & 0.005981147 \\
\hline 016 & 9.159645356 & 112.558943 & 0.007461217 & 1.86864637 & 0.044 & $\mathrm{HH}$ & 11 & 0.012103057 \\
\hline 017 & 2.433667166 & 111.3545861 & -0.004304425 & -0.634164665 & 0.278 & - & 24 & -0.007148742 \\
\hline 018 & 1.288795694 & 119.4913986 & -0.011370445 & -1.033328876 & 0.128 & - & 22 & -0.016264959 \\
\hline 019 & 5.772279279 & 93.5505671 & -0.011904918 & -1.805523987 & 0.02 & $\mathrm{HL}$ & 15 & -0.030526746 \\
\hline 020 & 77.01502484 & 4.310847146 & $-2.69606 \mathrm{E}-05$ & -0.028552754 & 0.228 & - & 1 & $4.00404 \mathrm{E}-05$ \\
\hline 021 & 5.827540297 & 39.46776655 & 0.007115157 & 1.770287707 & 0.02 & LL & 14 & -0.027965099 \\
\hline 022 & 4.836226834 & 83.74297027 & 0.00018264 & 0.205037776 & 0.26 & - & 2 & 0.00066871 \\
\hline 023 & 0.415659292 & 14.43489923 & 0.020400431 & 1.416291322 & 0.036 & LL & 15 & -0.036910218 \\
\hline 024 & 0.321622248 & 18.65542585 & 0.025864 & 1.876704738 & 0.012 & LL & 15 & -0.051479327 \\
\hline 025 & 0.201663089 & 4.958765662 & 0.035010541 & 1.442291566 & 0.024 & LL & 15 & -0.052598772 \\
\hline 026 & 0.233895101 & 38.47878805 & 0.015023239 & 1.734740977 & 0.014 & LL & 15 & -0.056432968 \\
\hline 027 & 0.524453793 & 22.88094807 & 0.019272681 & 1.230817008 & 0.068 & - & 15 & -0.042632365 \\
\hline 028 & 0.478334564 & 62.71760871 & -0.00111759 & -1.541090036 & 0.008 & HL & 16 & -0.04945287 \\
\hline 030 & 0.561350404 & 1.781418509 & 0.037086594 & 1.825113834 & 0.01 & LL & 15 & -0.052719193 \\
\hline 031 & 0.252174583 & 3.965506699 & 0.037865571 & 1.756201831 & 0.008 & LL & 16 & -0.055894254 \\
\hline 032 & 0.580194553 & 8.617798926 & 0.027070382 & 1.549926773 & 0.028 & LL & 16 & -0.043520348 \\
\hline 033 & 0.522154356 & 1.915142503 & 0.020374635 & 1.757167935 & 0.024 & LL & 18 & -0.029028623 \\
\hline 034 & 0.608065523 & 1.644559611 & 0.009971823 & 1.031768244 & 0.124 & - & 20 & -0.014142324 \\
\hline
\end{tabular}




\subsubsection{Kapuk RW 012}

In Kapuk RW 012 area, $58.81 \%$ of the area was planned as green open space or blue open space zone, $29.43 \%$ as a residential zone, and $11.77 \%$ as a commercial zone. The average level of building density in the $\mathrm{HH}$ cluster was 179.39 units/ha, which categorized into medium category, and this cluster occupied a residential zone and then grew into the green open space zone. For LL clusters, based on the results during observing aerial photo maps and building information maps, these locations were worked for commercial zones and burial grounds. Cluster and outlier analysis results map and spatial detail planning map for Kapuk RW 12 can be seen on Figure 5. The Cluster and outlier analysis results could be seen on Table 4.
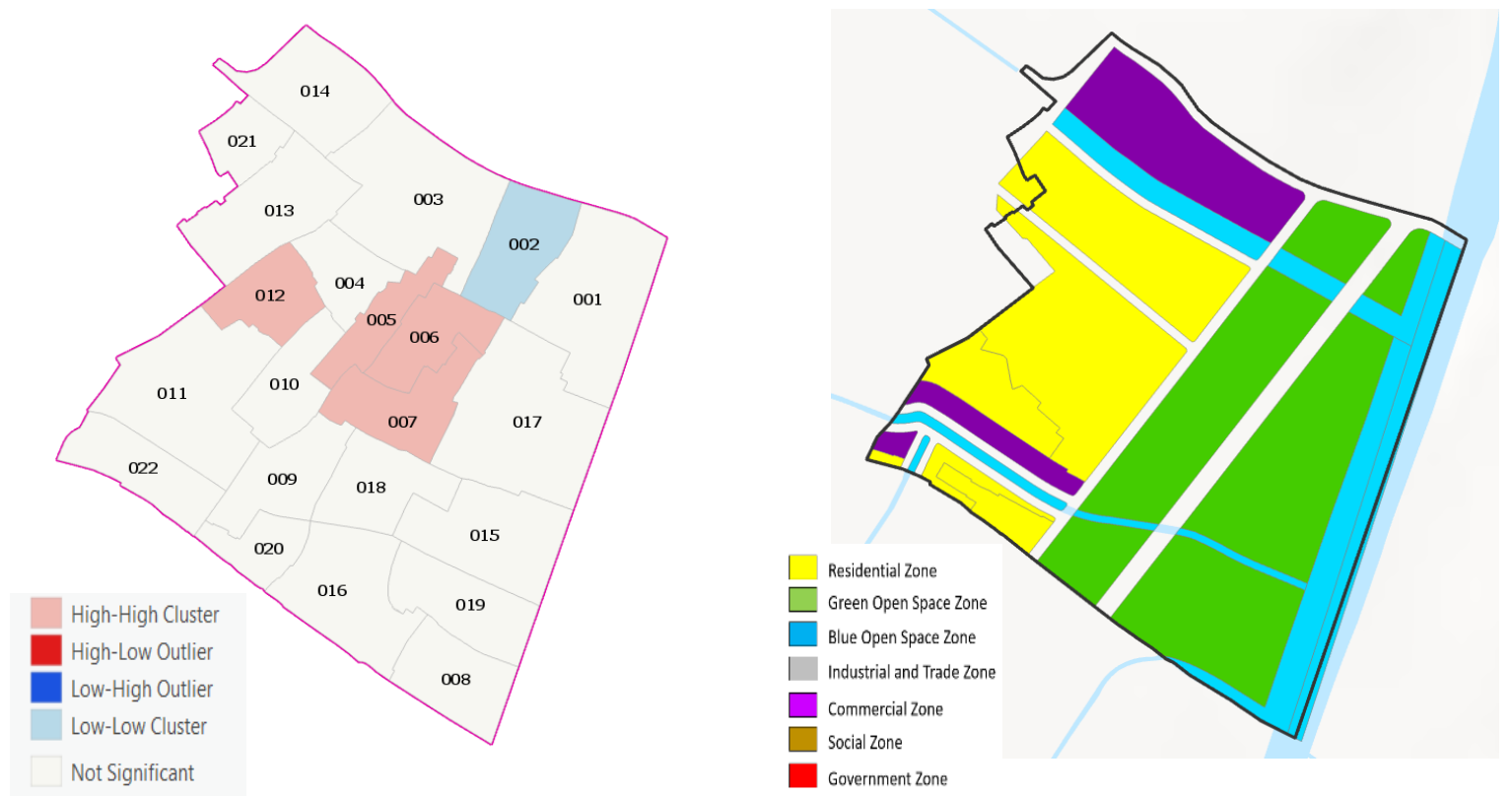

Figure 5. (a) Cluster and outlier analysis results map, (b) Spatial detail planning map

Table 4. Cluster and Outlier Analysis Results of Kapuk RW 012

\begin{tabular}{ccccccccc}
\hline RT Number & Area $(\mathrm{Ha})$ & $\begin{array}{c}\text { Building Density } \\
\text { Level }\end{array}$ & Lmi Index & Z-Score & P-Value & $\begin{array}{c}\text { Co- } \\
\text { Type }\end{array}$ & $\begin{array}{c}\text { Neigh- } \\
\text { bors }\end{array}$ & Spatial Lag \\
\hline 001 & 3.050279876 & 63.27288244 & 0.013005688 & 1.383595715 & 0.066 & - & 1 & -0.01011694 \\
002 & 1.602879138 & 68.62650926 & 0.020564999 & 1.855241209 & 0.036 & LL & 2 & -0.017500441 \\
003 & 3.423131314 & 79.4594116 & 0.001705587 & 0.20036579 & 0.428 & - & 2 & -0.001792192 \\
004 & 1.071603848 & 165.1729791 & 0.022594483 & 1.599814094 & 0.07 & - & 5 & 0.027681558 \\
005 & 1.01385894 & 215.02005 & 0.091155771 & 2.95665696 & 0.002 & HH & 5 & 0.049424034 \\
006 & 1.28523603 & 184.4019265 & 0.054167684 & 2.500547328 & 0.002 & HH & 3 & 0.044661859 \\
007 & 1.605481942 & 176.8939236 & 0.047054637 & 2.996412639 & 0.002 & HH & 4 & 0.044475847 \\
008 & 1.537244856 & 113.8400297 & 0.002126715 & 0.903418694 & 0.282 & - & 1 & -0.00876811 \\
009 & 1.589758677 & 164.8048875 & 0.017564833 & 1.522328007 & 0.078 & - & 3 & 0.021721542 \\
010 & 1.328513767 & 188.932931 & 0.022516053 & 1.470343221 & 0.084 & - & 5 & 0.017236573 \\
011 & 3.339938804 & 49.10269607 & -0.009542732 & -0.506884261 & 0.318 & - & 2 & 0.006048102 \\
012 & 1.23188494 & 141.2469577 & 0.010045428 & 2.041435921 & 0.016 & HH & 4 & 0.031125746 \\
013 & 2.237282831 & 120.2351336 & -0.001570291 & -0.799388461 & 0.21 & - & 3 & 0.01419185 \\
014 & 1.932980531 & 68.80565937 & -0.004851992 & -0.415373767 & 0.394 & - & 1 & 0.004141982 \\
015 & 2.334479253 & 87.81401667 & 0.010465548 & 1.213058723 & 0.132 & - & 2 & -0.013428443 \\
016 & 2.381764559 & 141.9115919 & 0.000943805 & 0.31907043 & 0.376 & - & 3 & 0.002805225 \\
017 & 3.58094228 & 91.87525916 & 0.003578863 & 0.797924913 & 0.35 & - & 1 & -0.00514507 \\
018 & 1.573707442 & 156.9542047 & 0.012007035 & 1.57992754 & 0.082 & - & 3 & 0.018566322 \\
019 & 1.682986199 & 84.96801702 & 0.007066262 & 0.670539879 & 0.282 & - & 3 & -0.008431714 \\
020 & 0.873744495 & 151.0739132 & 0.005892325 & 0.880595533 & 0.23 & - & 2 & 0.011214395 \\
021 & 0.841537554 & 147.3493362 & -0.005376213 & -0.792084643 & 0.242 & - & 2 & -0.011984346 \\
022 & 1.528143157 & 101.4302877 & 0.006741018 & 1.591998624 & 0.052 & - & 1 & -0.013522301 \\
\hline
\end{tabular}




\subsubsection{Penjaringan RW 008}

In Penjaringan RW 08 area, $46.96 \%$ of the area was planned as a commercial zone, $28.99 \%$ as industrial and trade zone, only $11.16 \%$ as a residential zone, $8.06 \%$ as a social and government zone and $4.83 \%$ as green open space or blue open space zone. The average level of building density in the $\mathrm{HH}$ cluster was 241.88 units/ha, which categorized into high category. The area of HH cluster was an average of $81 \%$ in the residential zone, all RT's outside this cluster were located within commercial zones and industrial zones. The LH cluster and LL cluster were put in locations that designated as industrial and trade zones, despite people settled in the area. Cluster and outlier analysis results map and spatial detail planning map for Penjaringan RW 008 is presented on Figure 6. The map reveals the impact of industrial zones and commercial zones towards slum areas. The Cluster and outlier analysis results can be seen on Table 5.
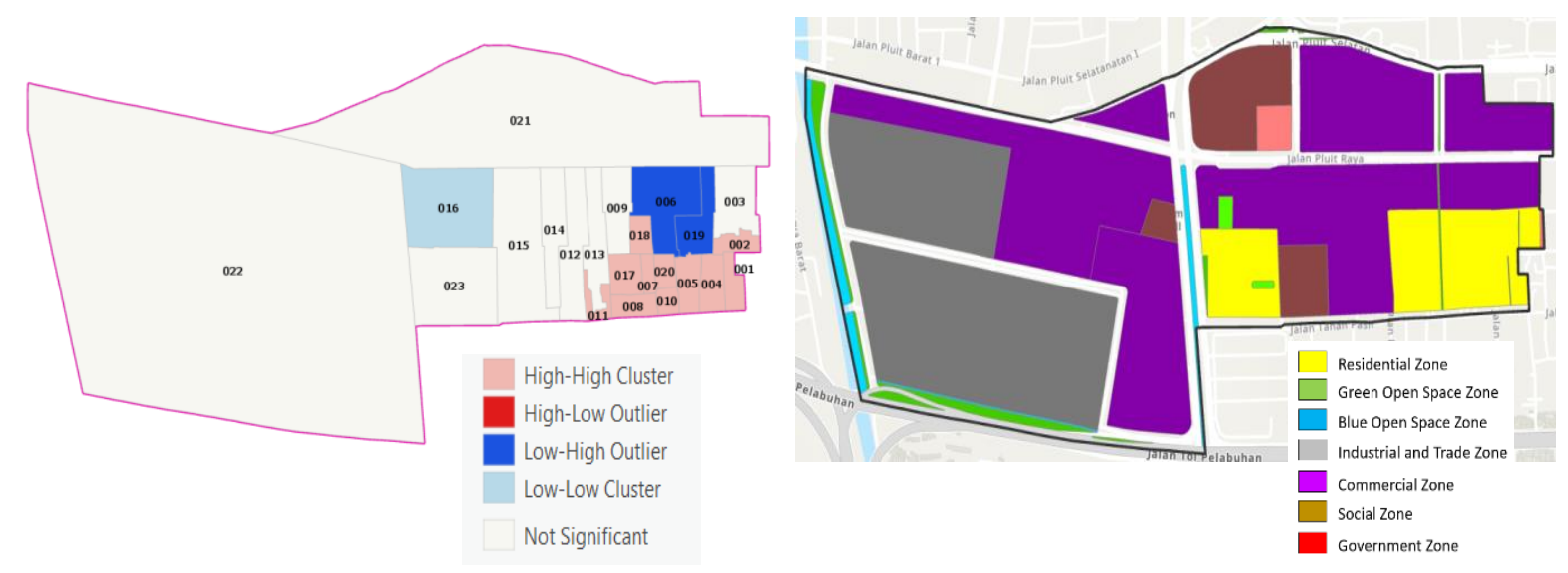

Figure 6. (a) Cluster and outlier analysis results map, (b) Spatial detail planning map

Table 5. Cluster and Outlier Analysis Results Penjaringan RW 008

\begin{tabular}{|c|c|c|c|c|c|c|c|c|}
\hline RT Number & Area (Ha) & $\begin{array}{c}\text { Building Density } \\
\text { Level }\end{array}$ & Lmi Index & Z-Score & P-Value & $\begin{array}{l}\text { Co- } \\
\text { Type }\end{array}$ & $\begin{array}{l}\text { Neigh- } \\
\text { bors }\end{array}$ & Spatial Lag \\
\hline 001 & 0.495802821 & 244.0486317 & 0.035181464 & 1.977457897 & 0.026 & $\mathrm{HH}$ & 18 & 0.035410012 \\
\hline 002 & 0.452813873 & 147.9636645 & 0.00340027 & 1.85192352 & 0.03 & $\mathrm{HH}$ & 18 & 0.030411088 \\
\hline 003 & 1.487034681 & 70.61032358 & -0.012887621 & -1.426214046 & 0.082 & - & 19 & 0.021550046 \\
\hline 004 & 0.739700924 & 178.4505004 & 0.024978276 & 2.593193752 & 0.008 & $\mathrm{HH}$ & 18 & 0.063789024 \\
\hline 005 & 0.709476909 & 207.1949038 & 0.04808212 & 3.239845847 & 0.002 & $\mathrm{HH}$ & 19 & 0.073368285 \\
\hline 006 & 2.299074609 & 80.90211568 & -0.012279053 & -1.774914495 & 0.028 & LH & 20 & 0.024383117 \\
\hline 007 & 0.271360063 & 361.1437843 & 0.140781393 & 3.33463788 & 0.002 & $\mathrm{HH}$ & 21 & 0.068073355 \\
\hline 008 & 0.539745467 & 155.6289123 & 0.012273384 & 3.848469814 & 0.002 & $\mathrm{HH}$ & 21 & 0.067380165 \\
\hline 009 & 1.217307666 & 76.39810595 & -0.007389487 & -0.797000292 & 0.198 & - & 21 & 0.013560685 \\
\hline 010 & 0.309755994 & 229.2126752 & 0.060621196 & 3.725490858 & 0.002 & $\mathrm{HH}$ & 20 & 0.070703378 \\
\hline 011 & 0.354582012 & 304.5839785 & 0.024249285 & 1.997014978 & 0.024 & $\mathrm{HH}$ & 21 & 0.015654237 \\
\hline 012 & 1.854919545 & 79.78782714 & 0.003178869 & 0.481377685 & 0.356 & - & 21 & -0.006186812 \\
\hline 013 & 1.367295966 & 62.1664966 & -0.008427159 & -0.380773793 & 0.382 & - & 21 & 0.012475107 \\
\hline 014 & 1.498585816 & 31.36290194 & 0.010542954 & 0.963948072 & 0.18 & - & 21 & -0.011002978 \\
\hline 015 & 4.008211452 & 10.22900126 & 0.010665893 & 1.157341626 & 0.15 & - & 21 & -0.009257553 \\
\hline 016 & 3.667775876 & 30.26357219 & 0.01191103 & 1.775755486 & 0.04 & LL & 14 & -0.012301236 \\
\hline 017 & 0.713209099 & 210.3170026 & 0.043696009 & 3.241898475 & 0.002 & $\mathrm{HH}$ & 21 & 0.063882751 \\
\hline 018 & 0.437556513 & 196.5460404 & 0.0181026 & 2.454770154 & 0.008 & $\mathrm{HH}$ & 21 & 0.032463326 \\
\hline 019 & 1.109129785 & 102.7832825 & -0.009126339 & -1.847478581 & 0.032 & LH & 19 & 0.030140513 \\
\hline 020 & 0.374971588 & 306.689903 & 0.127608409 & 3.619860606 & 0.002 & $\mathrm{HH}$ & 21 & 0.081363146 \\
\hline 021 & 20.2275822 & 5.635868828 & 0.005646748 & 1.414963492 & 0.078 & - & 18 & -0.004728168 \\
\hline 022 & 55.5765592 & 7.233265352 & 0.002338318 & 1.161014202 & 0.132 & - & 1 & -0.001982265 \\
\hline 023 & 3.533284563 & 23.77391306 & 0.009257242 & 1.434316635 & 0.072 & - & 15 & -0.009006569 \\
\hline
\end{tabular}




\subsubsection{Kalibaru RW 007}

In Kalibaru RW 007 area, $89.25 \%$ of the area was plotted as an industrial and trade zone and $10.75 \%$ as green open space or blue open space zone. The average level of building density in the HH cluster was153.05 units/ha, which categorized into medium category. Within this RW, there was no area had spatial detail planning for residential zones. The $\mathrm{HH}$ cluster was $100 \%$ in the industrial zone.Cluster and outlier analysis results map and spatial detail planning map for Kalibaru RW 007is presented on Figure 7. This map reveals the impact of industrial upon slum areas. The Cluster and outlier analysis results is shown on Table 6.
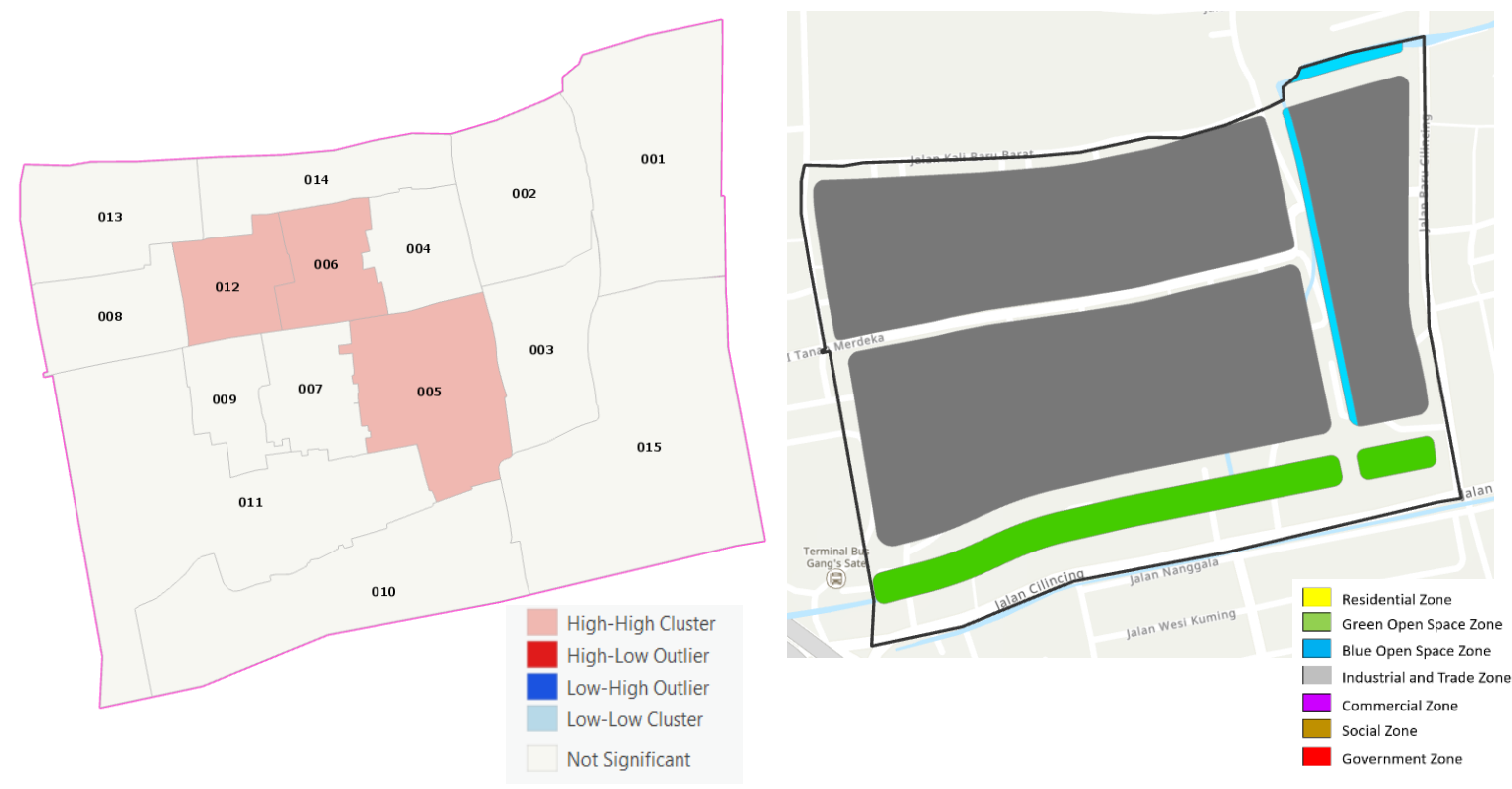

Figure 7. (a) Cluster and outlier analysis results map, (b) Spatial detail planning map

Table 6. Cluster and Outlier Analysis Results Kalibaru RW 007

\begin{tabular}{ccccccccc}
\hline RT Number & Area (Ha) & $\begin{array}{c}\text { Building Density } \\
\text { Level }\end{array}$ & Lmi Index & Z-Score & P-Value & $\begin{array}{c}\text { Co- } \\
\text { Type }\end{array}$ & $\begin{array}{c}\text { Neigh- } \\
\text { bors }\end{array}$ & Spatial Lag \\
\hline 001 & 1.737144174 & 99.58874027 & 0.00458499 & 0.509644235 & 0.284 & - & 1 & -0.005055485 \\
002 & 1.055307687 & 124.1344127 & -0.002695798 & -0.291010523 & 0.404 & - & 3 & 0.005994252 \\
003 & 0.84579522 & 169.0716579 & -0.005497731 & -0.688305876 & 0.246 & - & 4 & -0.014195057 \\
004 & 0.576624363 & 201.1708272 & 0.01444728 & 0.940784057 & 0.18 & - & 5 & 0.014664336 \\
005 & 1.211330157 & 152.7246712 & 0.002984804 & 1.931780157 & 0.022 & HH & 3 & 0.036044119 \\
006 & 0.549578745 & 151.0247634 & 0.003037311 & 2.086063318 & 0.006 & HH & 4 & 0.059384902 \\
007 & 0.585524499 & 239.1018655 & 0.014094885 & 0.76339319 & 0.254 & - & 5 & 0.00833166 \\
008 & 0.672974678 & 130.7627208 & -0.00464367 & -0.651168343 & 0.27 & - & 3 & 0.014232711 \\
009 & 0.46403552 & 185.3306404 & 0.01278412 & 1.010676774 & 0.152 & - & 4 & 0.018523708 \\
010 & 1.875343705 & 75.71945323 & 0.009775126 & 1.00673682 & 0.196 & - & 1 & -0.007232595 \\
011 & 2.86229691 & 106.2084087 & -0.01056085 & -0.666811523 & 0.292 & - & 3 & 0.013476807 \\
012 & 0.559880211 & 155.3903823 & 0.005647758 & 1.991396856 & 0.03 & HH & 6 & 0.042636513 \\
013 & 0.934507631 & 168.0029084 & -0.001303836 & -0.067590477 & 0.474 & - & 2 & -0.003548897 \\
014 & 0.761461633 & 215.3752638 & 0.017805913 & 0.983593321 & 0.18 & - & 3 & 0.014247248 \\
015 & 2.708752569 & 50.57678637 & -0.00776916 & -0.32882532 & 0.296 & - & 1 & 0.004269095 \\
\hline
\end{tabular}




\subsubsection{Kalibaru RW 004}

In Kalibaru RW 04 area, $72.25 \%$ of the area was expected to be green open space or blue open space zone and $27.75 \%$ as industrial and trade zone. The average level of building density in the HH cluster was 299.13 units/ha, that turned to be high category. Furthermore, the highest indicator was 250 units/ha. Within this RW, there was noarea had spatial detail planningfor residential zones. The $\mathrm{HH}$ cluster was $100 \%$ of the industrial zone. LL cluster was performed for fish auction, thusthe building was better organized and less dense compared to residential area, although this area was expected as a blue open space zone. Cluster and outlier analysis results map and spatial detail planning map for Kalibaru RW 004 is presented on Figure 8. This map illustrates the impact of industrial towards slum areas. The Cluster and outlier analysis resultscould be observed on Table 7.
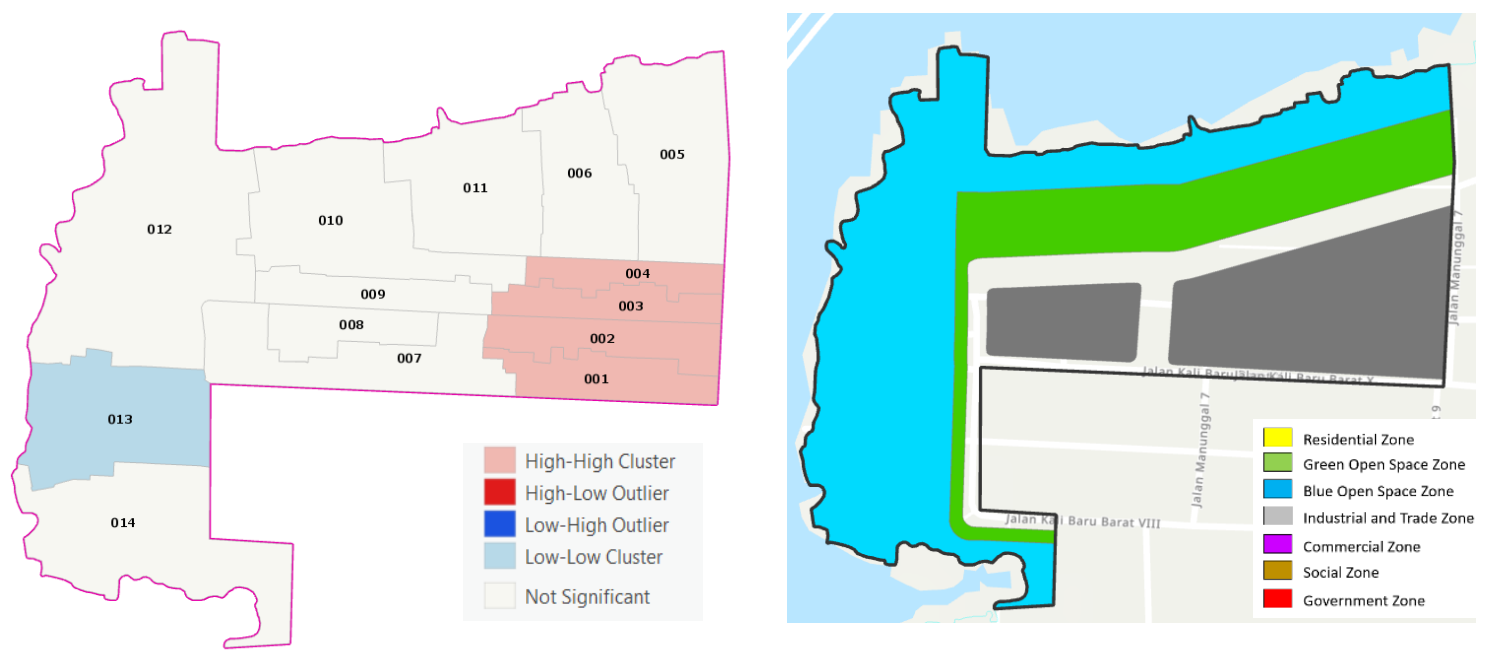

Figure 8. (a) Cluster and outlier analysis results map, (b) Spatial detail planning map

Table 7. Cluster and Outlier Analysis Results of Kalibaru RW 004

\begin{tabular}{ccccccccc}
\hline RT Number & Area (Ha) & $\begin{array}{c}\text { Building Density } \\
\text { Level }\end{array}$ & Lmi Index & Z-Score & P-Value & $\begin{array}{c}\text { Co- } \\
\text { Type }\end{array}$ & $\begin{array}{c}\text { Neigh- } \\
\text { bors }\end{array}$ & Spatial Lag \\
\hline 001 & 0.436869348 & 235.7684293 & 0.024902118 & 2.239643163 & 0.01 & HH & 3 & 0.094305378 \\
002 & 0.456607682 & 310.9890737 & 0.116878753 & 2.089503004 & 0.022 & HH & 4 & 0.101034507 \\
003 & 0.350335746 & 353.946183 & 0.137817159 & 2.206303646 & 0.018 & HH & 6 & 0.082690636 \\
004 & 0.283954308 & 295.8222424 & 0.085300183 & 2.104603301 & 0.026 & HH & 6 & 0.087325124 \\
005 & 1.054127606 & 126.170683 & -0.023863091 & -1.126039608 & 0.166 & - & 3 & 0.02301808 \\
006 & 0.723276474 & 193.5636027 & -0.005356458 & -0.867204751 & 0.194 & - & 5 & 0.022615129 \\
007 & 0.839642029 & 152.445918 & -0.02602809 & -0.640549153 & 0.284 & - & 3 & 0.03590769 \\
008 & 0.351977421 & 230.1283976 & -0.000381847 & -0.014604488 & 0.486 & - & 4 & -0.001937138 \\
009 & 0.388837959 & 329.1859679 & -0.031896561 & -0.417994391 & 0.388 & - & 4 & -0.023234821 \\
010 & 1.170541928 & 175.9868613 & -0.007655461 & -0.677320645 & 0.26 & - & 4 & 0.017185376 \\
011 & 0.896925791 & 177.2721909 & -0.01288667 & -1.556943245 & 0.068 & - & 6 & 0.029954463 \\
012 & 2.353795432 & 124.9046523 & 0.003343953 & 0.548240084 & 0.464 & - & 1 & -0.003179458 \\
013 & 0.986840146 & 179.3603561 & 0.009617887 & 1.843403771 & 0.01 & LL & 2 & -0.023722966 \\
014 & 1.339964566 & 103.7340864 & 0.006273934 & 0.562931197 & 0.466 & - & 1 & -0.004814987 \\
\hline
\end{tabular}




\subsection{Socio-economic Condition Observation}

A brief observation of the socio-economic factors was conducted and decided that $6 \mathrm{RW}$ locations were selected based on the Dasawisma Census of Family Welfare Empowerment 2019 results. The observation was comparing the categories of analysis clusters and outliers which are presented on Table 8. Considering the socio-economic conditions observation of six RW's based on analysis results of clustering and outlier, education and income factors did not significantly affect the building density in the area. However, for family factors that were active in community environmental activities, two regions have $\mathrm{HH}$ were categorized with percentages much lower than other categories (LL, LH, and HL) namely Kapuk RW 016 and Kalibaru RW 004.

Table 8. Socio-economic Conditions for 6 (Six) Slum Areas

\begin{tabular}{|c|c|c|c|}
\hline $\begin{array}{c}\text { Location/ } \\
\text { Cluster - Outlier }\end{array}$ & $\begin{array}{l}\text { \% of Average } \\
\text { Education is } \\
\text { elementary school }\end{array}$ & $\begin{array}{c}\% \text { of Average } \\
\text { families active } \\
\text { in the community }\end{array}$ & $\begin{array}{c}\% \text { of Average } \\
\text { Revenue Category } \\
0-5 \text { million/month }\end{array}$ \\
\hline \multicolumn{4}{|l|}{$\overline{\text { Kapuk RW } 016}$} \\
\hline $\mathrm{HH}$ & 0.243635 & 0.532892 & 0.967116 \\
\hline LH & 0.229358 & 0.908257 & 0.844037 \\
\hline $\mathrm{LL}$ & 0.182019 & 0.730123 & 0.938806 \\
\hline Not Significant & 0.225758 & 0.659241 & 0.940755 \\
\hline \multicolumn{4}{|l|}{ Penjaringan $R W 017$} \\
\hline $\mathrm{HH}$ & 0.547804 & 0.976744 & 0.281654 \\
\hline HL & 0.134615 & 0.990385 & 0.298077 \\
\hline LH & 0.476021 & 0.919210 & 0.249729 \\
\hline $\mathrm{LL}$ & 0.121622 & 1.000000 & 0.216216 \\
\hline Not Significant & 0.222666 & 0.412545 & 0.959620 \\
\hline \multicolumn{4}{|l|}{ Kapuk RW 012} \\
\hline $\mathrm{HH}$ & 0.166345 & 0.305419 & 0.982918 \\
\hline $\mathrm{LL}$ & - & - & - \\
\hline Not Significant & 0.163368 & 0.391151 & 0.926129 \\
\hline \multicolumn{4}{|l|}{ Penjaringan $R W 008$} \\
\hline $\mathrm{HH}$ & 0.181128 & 0.416882 & 0.938323 \\
\hline LH & 0.150148 & 0.476811 & 0.987539 \\
\hline $\mathrm{LL}$ & - & - & - \\
\hline Not Significant & 0.135797 & 0.215532 & 1.000000 \\
\hline \multicolumn{4}{|l|}{ Kalibaru RW 007} \\
\hline $\mathrm{HH}$ & 0.300550 & 0.331892 & 0.912108 \\
\hline Not Significant & 0.385699 & 0.234935 & 0.986591 \\
\hline \multicolumn{4}{|l|}{ Kalibaru RW 004} \\
\hline $\mathrm{HH}$ & 0.314215 & 0.277953 & 0.966667 \\
\hline LL & 0.426230 & 0.721311 & 0.967213 \\
\hline Not Significant & 0.302216 & 0.428198 & 0.964598 \\
\hline
\end{tabular}

Source: Dasawisma Census 2019 Dataset, Jakarta Family Welfare Empowerment Team

The current study discussed the analysis results of the 6 RW's heavy slum category with two RWs located exactly alongside the coastal. The analysis was performed to reveal the fact 
that slums did not cover the entire RW area by analyzing patterns of distribution of building densities to smaller areas, that were areas based on RT administrative boundaries.

The results show that slum locations had direct neighbors to areas were designated as industrial zones and warehousing areas as well as office, trade and service zones, obtained a higher level of building density compared to slum locations that had neighbors to areas that were designated as housing zones according to Jakarta spatial detail planning. These results are in accordance with (Roy \& Lees, 2020) which revealed attractive economic opportunities would likely attract residents of slums. In addition, (Takyi et al., 2020) stated where all slum areas in their analysis were located around the Central Business District. The result is also in line with (Badmos et al., 2020) that discovered a factor influenced the choice of residence for slum was markets adjacency. Zain et al., (2018) in his research indicated that engaging space for the development of the trade and services area had an impact on the growth of slums.

The expansion of an area or space interm of developing trade and services is proportional to the growth of slums which could also escalate regional microeconomic growth, where slum dwellers operate small-scale businesses (Zain et al., 2018). Slums are growing near strategic areas including business centers, trade, markets, or industries (Badmos et al., 2020; Prianto \& Amalia, 2019; Zain et al., 2018). Slums also contribute to the development of a nearby business district, since this sector could provide man power to support the operations of the business district (Ray, 2017), and most of the dwellers make living close the slum (Saika \& Matsuyuki, 2017). This condition could be observed clearly, where within slums there is a great human potential to support a region's sustainable development policy by involving local communities and civil society (Elrayies, 2016).

The results also show that slum areas are not a concentrated population with low income and/or low education. These results are supported by (Roy et al., 2018) and (Uddin, 2018) where income levels vary among residents in slums. There are land owners and land tenants upon socio-economic system that have been established for a long time in slums, and the arrival of poor individuals who stepped in into this circle has no impact towards overall environment (Duah \& Bugri, 2016; Nakamura, 2016). The impression of poverty attached to slums is a result of building density, while slums located in the downtown perform good economic opportunities (Bird et al., 2017).

This study is considered essential to investigate the priority location of slum improvement management, hence it was right on target. Studies based on spatial analysis of physical indicators of building density would complement previous studies conducted based on population censuses, as those studies were able to reduce bias data, where population data were not equivalent to location of residence. 


\section{Conclusion}

Applying cluster and outlier modeling of building density levels of urban slums in Jakarta based on RT boundary level revealed more specific slum locations and identified factors that influencing differences of building density levels. Slum locations that had direct neighbors to areas designated at Jakarta spatial detail planning as industrial zones and warehousing areas as well as office, trade and service zones, possed a higher level of building density compared to slum locations that had neighbors to areas that were designated as housing zones. This current study showed the level of income and education in each RT area did not significantly providing influence upon slum area. Further studies could be applied by analyzing the level of building density in all areas of Jakarta combined with other variables to obtain more specific slum distribution clusters. This study suggests that DKI Jakarta Provincial Government could determine the more appropriate solution based on the characteristics of each slum area in dealing with slum improvement in Jakarta.

\section{Conflict of Interests}

The authors declare that there is no conflict of interest with any financial, personal, or other relationships with other people or organizations related to the material discussed in the article.

\section{Acknowledgment}

Authors would like to appreciate DKI Jakarta Provincial Government for their data support and maps during the study.

\section{References}

Adedayo, A., \& Malik, N. (2015). Factors influencing the growth of slums in Lagos metropolis, Nigeria. Ethiopian Journal of Environmental Studies and Management, 8(2), 113. https://doi.org/10.4314/ejesm.v8i2.1.

Anselin, L. (1995). Local Indicators of Spatial Association-LISA. Geographical Analysis, 27(2), 93-115. https://doi.org/10.1111/j.1538-4632.1995.tb00338.x.

Arribas-Bel, D., Garcia-López, M., \& Viladecans-Marsal, E. (2019). Building(s and) cities: Delineating urban areas with a machine learning algorithm. Journal of Urban Economics, October, 103217. https://doi.org/10.1016/j.jue.2019.103217.

Badmos, O. S., Callo-Concha, D., Agbola, B., Rienow, A., Badmos, B., Greve, K., \& Jürgens, C. (2020). Determinants of residential location choices by slum dwellers in Lagos megacity. Cities, 98(December 2019), 102589. https://doi.org/10.1016/j.cities.2019.102589.

Bird, J., Montebruno, P., \& Regan, T. (2017). Life in a slum: Understanding living conditions in Nairobi's slums across time and space. Oxford Review of Economic Policy, 33(3), 496-520. https://doi.org/10.1093/oxrep/grx036. 
De Bellefon, M. P., Combes, P. P., Duranton, G., Gobillon, L., \& Gorin, C. (2020). Delineating urban areas using building density. Journal of Urban Economics, November 2019. https://doi.org/10.1016/j.jue.2019.103226.

Duah, E., \& Bugri, J. T. (2016). Feasibility of Slum Redevelopment in Ghana: The Regenerative Approach. Sociology and Anthropology, 4(11), 987-1002. https://doi.org/10.13189/sa.2016.041106.

Elrayies, G. M. (2016). Rethinking Slums: An Approach for Slums Development towards $\begin{array}{llll}\text { Sustainability. Journal of Sustainable Development, } 9(6), & 225 .\end{array}$ https://doi.org/10.5539/jsd.v9n6p225.

Friesen, J., Rausch, L., Pelz, P., \& Fürnkranz, J. (2018). Determining Factors for Slum Growth with Predictive Data Mining Methods. Urban Science, 2(3), 81. https://doi.org/10.3390/urbansci2030081.

Kuffer, M., Pfeffer, K., \& Sliuzas, R. (2016). Slums from space-15 years of slum mapping using remote sensing. Remote Sensing, 8(6). https://doi.org/10.3390/rs8060455.

Leonita, G., Kuffer, M., Sliuzas, R., \& Persello, C. (2018). Machine learning-based slum mapping in support of slum upgrading programs: The case of Bandung City, Indonesia. Remote Sensing, 10(10). https://doi.org/10.3390/rs10101522.

Ministry of Public Works and Indonesian Public Housing-PUPR. (2016). Regulation Number 02/PRT/M/2016: Improving the Quality of Slum Housing and Areas. https://jdih.pu.go.id/internal/assets/assets/produk/PermenPUPR/2016/01/PermenPUPR022016.zip.

Nakamura, S. (2016). Revealing invisible rules in slums: The nexus between perceived tenure security and housing investment. Habitat International, 53, 151-162. https://doi.org/10.1016/j.habitatint.2015.11.029.

Pratomo, J., Kuffer, M., Martinez, J., \& Kohli, D. (2017). Coupling uncertainties with accuracy assessment in object-based slum detections, case study: Jakarta, Indonesia. Remote Sensing, 9(11). https://doi.org/10.3390/rs9111164.

Prianto, A. L., \& Amalia, A. A. (2019). Combatting Slums, Suistaining Poverty: Dynamic Urban Governance in Makassar, Indonesia. Otoritas : Jurnal Ilmu Pemerintahan, 9(1), $28-41$. https://doi.org/10.26618/ojip.v9i1.2008.

Ray, B. (2017). Quality of life in selected slums of Kolkata: a step forward in the era of pseudo$\begin{array}{llll}\text { urbanisation. } & \text { Local 36ronment, }\end{array}$ https://doi.org/10.1080/13549839.2016.1205571.

Roy, D., \& Lees, M. (2020). Understanding resilience in slums using an agent-based model. Computers, Environment and Urban Systems, 80(April 2019). https://doi.org/10.1016/j.compenvurbsys.2019.101458.

Roy, D., Lees, M. H., Palavalli, B., Pfeffer, K., \& Sloot, M. A. P. (2014). The emergence of slums: A contemporary view on simulation models. Environmental Modelling and Software, 59(2014), 76-90. https://doi.org/10.1016/j.envsoft.2014.05.004.

Roy, D., Palavalli, B., Menon, N., King, R., Pfeffer, K., Lees, M., \& Sloot, P. M. A. (2018). Survey-based socio-economic data from slums in Bangalore, India. Scientific Data, 5, 1-9. https://doi.org/10.1038/sdata.2017.200. 
Saika B. A. S., \& Matsuyuki, M. (2017). Applicability of Land Sharing Scheme to Korail Slum, Dhaka, Bangladesh. Urban and Regional Planning Review, 4(0), 151-167. https://doi.org/10.14398/urpr.4.151.

Takyi, S. A., Amponsah, O., Yeboah, A. S., \& Mantey, E. (2020). Locational analysis of slums and the effects of slum dweller's activities on the social, economic and ecological facets of the city: insights from Kumasi in Ghana. GeoJournal, 2. https://doi.org/10.1007/s10708020-10196-2.

Uddin, N. (2018). Assessing urban sustainability of slum settlements in Bangladesh: Evidence from Chittagong city. Journal of Urban Management, 7(1), 32-42. https://doi.org/10.1016/j.jum.2018.03.002.

UN Habitat. (2004). The Challenge of Slums: Global Report on Human Settlements 200320043 The Challenge of Slums: Global Report on Human Settlements 2003 . London: Earthscan 2003. 310 pp.

United Nations. (2019). The sustainable development goals report 2019. In United Nations publication issued by the Department of Economic and Social Affairs. https://undocs.org/E/2019/68.

Wati, A. (2018). Keterikatan Tempat Bermukim Pada Permukiman Kumuh Di Manggarai, Jakarta-Selatan. Jurnal Ilmiah Desain \& Konstruksi, 17(1), 1-10.

Wijaya, A., Ardalia, F., \& Dewi, E. P. (2019). Pemanfaatan Ruang Komunal Pada Kawasan Permukiman Kumuh Perkotaan Di Manggarai Jakarta Selatan. IKRA-ITH TEKNOLOGI: Jurnal Sains \& Teknologi, 3(2), 17-26.

Zain, D. P., Salman, D., \& Baja, S. (2018). Model of slum area management based on sociospatial approach. The case of Baubau City, Indonesia. Journal of Settlements and Spatial Planning, 9(2), 103-115. https://doi.org/10.24193/JSSP.2018.2.03. 